\title{
Impact of HR Policies on Employee Motivation in Private Schools of Karachi, Pakistan.
}

\author{
Amna Umer * Akhtar Ahmed Khalil ${ }^{\dagger} \quad$ Abid Shirwani ${ }^{\ddagger}$
}

\begin{abstract}
This study investigates the influence of HR policies and practices on the motivation of employees in private schools. Relevant information is gathered from school teachers in Karachi through a questionnaire while the sample size includes 512 responses. The statistical tool applied in this study is partial least square structural equation model (PLS-SEM). Findings show that compensation, employee empowerment, fair job appraisal, employee recognition and job satisfaction have a positive and significant relationship with the employee motivation, concluding that these factors of HR policies motivate employees. This study provides management insights into different ways to incorporate strategies in order to motivate their employees.
\end{abstract}

Keywords: Compensation, employee empowerment, fair job appraisal, employee recognition and job satisfaction, employee motivation.

\section{Introduction}

In today's world, getting employees to perform effectively is one of the most challenging tasks that a manager could face. In fact, interpreting what motivates a human being is still an enigma (Nohria, Groysberg, \& Lee, 2008). According to Kreitner (1995), motivation is a psychological process that gives behavior, purpose and direction. Every person has a different set of motivational factors that influence her. Why do we need motivated employees? The answer is survival of the organization (Smith, 1994). Encouraging and inspiring workers to achieve the goal of an organization is a tough mission, yet it is vital for success in the corporate world. Demotivation of employees can be costly as it can lead to low performance, disruption, turnover, and absenteeism. As described by Locke, Shaw, Saari, and Latham (1981), job motivation is the sequence of motivating powers, which are initiated from inside and outside of a person's self and these powers lead to the creation of job-related attitude along with the ascertainment of the nature, dimension, strength and duration of the person's attitude.

In an organization, employees are the basis of providing competitive advantage and its human resource procedures directly impact the employees (Delery \& Shaw, 2001). Efficient Human Relation (HR) management policies are the prime sources which can lead

\footnotetext{
${ }^{*}$ Research Associate, Department of Management Sciences, Iqra University, Karachi, Pakistan, 75300.

E-mail: amna.umer@live.com

${ }^{\dagger}$ Assistant Professor \& Director Students Placement, DHA Sufa University, Karachi, Pakistan.

E-mail: col.akhtar@dsu.edu.pk

${ }^{\ddagger}$ Director General, University of Management and Technology, Lahore, Pakitan. Email: abid@umt.edu.pk
} 
to the success of an organization (Stavrou, 2005). Moreover, human resource experts can elevate their workers' abilities of handling change and also assist successful change management (Kalyani \& Sahoo, 2011), since dealing with change includes dealing with workers' behavior and previous studies have revealed that there is a robust relationship between human resource practices and worker's behavior (Mossholder, Richardson, \& Settoon, 2011). Kleiner (1990) suggests that the influence of human resource management (HRM) policies and practices on an organization's productivity is a significant matter in the domain of HRM, industrial relations and firm's psychology. Different combination of HR practices has been studied by organizations according to their requirements, however, some literature concentrates solely on the specific HRM practices and their specific results (Laursen, Foss, et al., 2000). Usually, HR practices may involve the employee selection practices emphasizing on the generation of human capital; compensation policies emphasizing worker's motivation; training programs and performance evaluations targeting on the development of intellectual capital and the growth of an organization (Tsui, Pearce, Porter, \& Tripoli, 1997). Furthermore, HR guidelines assist firm's structure (Molineux, 2013), direct employees to meet the expectations of an organization (Lawler, 2003), and synchronize the people management activities with the whole business strategy.

A human resource management system is of immense importance in any kind of organization, whether they are multi national companies, hospitals, technology related organizations or schools/universities (Hong, Hao, Kumar, Ramendran, \& Kadiresan, 2012; Sial, Jilani, Imran, \& Zaheer, 2011). The educational sector of any country plays an essential part in its development. Similarly,in Pakistan this sector is becoming significant since experts suggest that financing it would result in the development of the country (Sial et al., 2011). However, the schools in Pakistan encounter issues such as the lack of motivation among the employees (Sial et al., 2011) and the inefficient incorporation of HR practices to address the issue in the educational sector. This causes teachers to puts little focus on the dissemination of knowledge, thus lowering the participation of students, compromising the quality of education, and increasing teachers' turnover rate (Sial et al., 2011). Through previous researches (Batt, 2002; Patterson, West, Lawthom, \& Nickell, 1997) it is evident that the effect of HR policies and practices has been investigated on productivity, performance, absenteeism and turnover, yet, the influence of these policies on employee motivation has scarcely been studied particularly in the context of school teachers in Pakistan.Therefore, there is a need to identify the policies of HR which can act as motivators for employees working in the private schools of Karachi, Pakistan.

\section{Literature Review}

\section{Theoretical background}

Generally, various motivational theories have been investigated in many researches. Maslow's Hierarchy of (1943), Herzberg's Two Factor Theory (1959)and Vroom's Expectancy Theory (1964) are among a few of them. Maslow's theory suggests that for a person to become fit and normal, his five needs or desires should be fulfilled. These five needs are in a hierarchical order, starting from the bottom, physiological needs, to the top which is a person's 
requirement to utilize his/her maximum potential. Moreover, Herzberg proposes two factors, extrinsic and intrinsic, which are connected with the satisfaction or dissatisfaction of work. Extrinsic factors or hygiene factors, associated with the work settings, result in dissatisfaction in their absence, whereas intrinsic factors or motivators, associated with the degree of recognition in an organization, cause satisfaction by their presence. Furthermore, Vroom's expectancy theory recommends that there are three types of beliefs about the job, i) expectancy, ii) instrumentality, and iii) valence which lead to employee motivation. Expectancy refers to the belief that performance is the outcome of efforts, instrumentality belief links performance with reward while valence is the perceived worth of the reward (Baron, Greenberg, DeNisi, \& Goddard, 1990).

Many studies have been conducted in which different HR policies are considered as motivators (Hong et al., 2012; Turk, 2008). Moreover, the role of HR policies has also been investigated in other contexts such as the influence of HR policies on employee performance, employee change-related outcomes, turnover, productivity, corporate financial performance and employee commitment.

This research investigates specific policies of HR which act as motivators in order to determine employees' motivation. The factors studied in this research are: fair performance appraisal, job satisfaction, employee recognition, employee empowerment, and compensation. There is little evidence of literature which has used this set of motivators to investigate teachers' motivation from a Pakistan perspective. These factors are discussed further in the study.

\section{Empirical studies}

\section{Compensation}

Compensation refers to both monetary and non- monetary parts. Compensation usually involves basic pay along with other benefits (Martin, 2011). According to Van Herpen, Van Praag, and Cools (2005), compensation involves the complete set of rewards, performance appraisal programs and also career guidance. It is an organizational duty to fully implement and improve its compensation system (Turk, 2008). Studies have been carried out to investigate the impact of compensation on different other variables such as retention, motivation, organizational commitment and job satisfaction (Turk, 2008). According to Turk (2008), management should take measures in order to retain and motivate employees and Van Herpen et al. (2005) suggest that rewards are the source of motivation for employees. Lawson (2000) further recommends that in order to motivate employees, their salary and performance should be in harmony with each other. Moreover, money along with other corresponding features acts as a motivator. Various studies have indicated that compensation has a positive and significant impact on employee motivation (Hong et al., 2012; Turk, 2008). Therefore, the hypothesis would be:

H1: Compensation has a significant impact on employee motivation. 


\section{Employee empowerment}

Employee empowerment refers to giving the authority or allocating duties to the employees or it can also be regarded as the transfer of power (Quinn \& Spreitzer, 1997). Various ways are used to describe employee empowerment. Vogt (1990) describes it as a duration of refining the decision making capabilities of workers via assistance, contribution, training, learning and group effort. Furthermore, Klagge (1998) recognizes it as the action of allocating duties to the workers, allowing them to become capable of performing their duties effectively. These meanings suggest that there are two significant features of empowerment; cognitive and behavioral. Cognitive empowerment refers to the development of the capability of the worker within the firm, whereas the latter concerns with the satisfaction of the worker with his work and organization. Moreover, Conger and Kanungo (1988) propose empowerment to be a motivational perception since it improves workers' competency.

Spreitzer (1995) suggests that authorization should be incorporated in the system of an organization to not only enhance and develop the capabilities of the firm, but also to create the experience of self-empowerment among workers. This kind of empowerment shows that both management and motivational tools should be regarded together.

Moreover, empowerment can be regarded as passing on the authority of taking decisions and actions to the workers, while giving them authority and rights to finish their assignments according to their own will (Jarrar \& Zairi, 2002). It implies that workers have enough power to take decisions regarding the accomplishment of their work. Kaye and Jordan-Evans (2001) propose that the success of a firm, undoubtedly, occurs because of its empowered workforce since they are highly motivated and devoted towards the accomplishment of the firm's goal.

Furthermore, studies conducted by Tutar, Altinoz, and Cakiroglu (2011); Gagne, Senecal, and Koestner (1997) show that employee empowerment has a positive effect on motivation of the workers and ultimately on their performance. Therefore, it can be hypothesized that:

H2: Employee empowerment has a significant impact on employee motivation.

\section{Fair job appraisal}

According to Turk (2008) every employee needs his or her performance to be evaluated, documented and rewarded. This is done through a process of performance or job appraisal, which determines workers' job outcomes by affecting employees' self-confidence ands selfesteem and by motivating them to work harder in future. It also helps in comparing past performances of employees so that their work can be evaluated further. Performance appraisal also helps to identify and highlight performance and it not only focuses on the performance outcomes and compensation feature, but on building a better work environment, forming proficient administrative teams and improving workforce quality, which altogether creates extraordinary motivation and job satisfaction among the employees. Boyd (2004) and Weiss (2001) consider fair job evaluation as a management method utilized for taking decisions for employees regarding promotion, transfer, and compensation and for dealing with the matters of employee development through feedback and training. Performance appraisal is a significant factor of human resource management since managers utilize 
evaluation outcomes for decision making, organizational verdicts, and workers' growth. Performance appraisal should be incorporated as a basic human resource function (Lawler, Mohrman, \& Resnick, 1984). This appraisal can become a useless tool if it is regarded as unfair by the workers, whereas the same tool is accepted warmly if it is considered to be fair by them (Hui \& Qin-xuan, 2009). Performance evaluation motivates employees and as a result, they give maximum output (Lawson, 2000; Allan, 1994).

It can be seen through various researches (Turk, 2008; Jabeen, 2011) that fair job appraisal practice increases employee motivation. Therefore, the hypothesis will be:

H3: Fair job appraisal has a significant impact on employee motivation.

\section{Employee Recognition}

Employee recognition is the timely, informal or formal acknowledgment of a person's behavior or efforts that supports the organizational goals and values, and which has clearly been beyond normal expectations. According to Georgellis, Lange, Ileana Petrescu, and Simmons (2008), performance recognition is an acceptance or appreciation of the accomplishments and efforts made by the workers in order to achieve the objective of an organization. This involves noticing and considering workers' activities, struggles, attitudes or implementation which can be both tangible and intangible. Moreover, Alam, Shaheed, Sahabuddin, and Akter (2013) suggest that employee recognition is a strong way to lead the consideration inside a firm and so the management needs to comprehend the gist of complimenting the workers for their better efforts, and to inspire other workers to practice it in their colleague related associations. Chikungwa and Chamisa (2013) further explain that appreciation is an important requirement of a person, and for workers it reassures them that their efforts are acknowledged. Moreover, employees tend to give their maximum output and display elevated levels of satisfaction with their work when they realize that their efforts are being cherished and acknowledged, hence they are motivated to deliver their best. Employee recognition also builds an emotional connection amongst the employees and the organization (Stringer, Didham, \& Theivananthampillai, 2011). Manjunath and Rajesh (2012) express how employees have the capability and skills to reach up to their maximum level of output, yet they have a requirement to be motivated by the acknowledgment of their performance. Additionally, Lawler (1981) said that an elevated level of performance occurs because of the acknowledgment of the performance which happens as a consequence of increased satisfaction. Various researches have discovered that employee performance recognition has a positive and significant impact on employee motivation (Chikungwa \& Chamisa, 2013). Therefore the hypothesis would be:

H4: Employee recognition has a significant impact on employee motivation.

\section{Job Satisfaction}

Job satisfaction is basically a worker's affective response which compares anticipated results with the actual results (Cranny, Smith, \& Stone, 1992). It is regarded as employees' opinion held for their work which is created from their understanding about their work 
(O'Reilly, Chatman, \& Caldwell, 1991). Normally, it is considered to be a multidimensional variable involving both intrinsic and extrinsic features of work (Howard \& Frink, 1996). Job satisfaction is also described as how content an individual is with his or her job. According to Locke (1976), it is a pleasant or an optimistic emotional condition of an employee occurring from the evaluation of his or her work. Employee satisfaction along with empowerment they are granted, act as a strong factor which retains employees (Jaffery, Farooq, et al., 2015). Previous studies have suggested that when employees are satisfied, they show higher motivation to perform at work (Porter \& Lawler, 1968; Deci \& Vroom, 1992) and a significant positive association has been seen between work motivation and job satisfaction (Stringer et al., 2011; Pool, 1997). Therefore, the hypothesis would be:

H5: Job satisfaction has a significant impact on employee motivation.

\section{Employee motivation}

Motivation can be defined in various ways. Hellriegel and Slocum (1974) regard it as a tendency to perform in order to achieve an objective while Baron et al. (1990) suggest that it is an addition of performance which affects and leads attitude to accomplish a definite objective. Furthermore, two types of factors were described by Herzberg (1959): extrinsic and intrinsic which are both essential for determining employee motivation. Vroom (1964) stated that motivation can be defined by the results of the work. Various motivational designs have been utilized (Herzberg, 1959; Vroom, 1964), suggesting that increased levels of motivation are the outcome of the chances an individual gets to satisfy his or her psychological needs, in the organization which would, in turn, produce positive job-associated attitudes and overall health. Focusing on teachers, it is debated that teachers who are not encouraged by monetary compensation can be driven by non-monetary compensation (Tomlinson, 2000). Non-monetary compensation can involve contentment from a pupil's accomplishment, acknowledgment, inspiration, acquiring new expertise and personal development. Generally, motivational theories illustrate the variations in the requirements, objectives and opinions of teachers. Many teachers customize their roles in an institute in order to thoroughly associate their motivation with their distinct attributes. Hoy and Miskel (2005) purport that among various theories, two factor theory of Herzberg is widely acknowledged by managers. It has also been suggested that rewards act as motivators while punishments cause demotivation (Lawler III, 1973). Therefore, it is essential for the organization to keep rewarding and compensating workers not only for the excellence and performance, but also for triggering innovation. 


\section{Conceptual Framework}

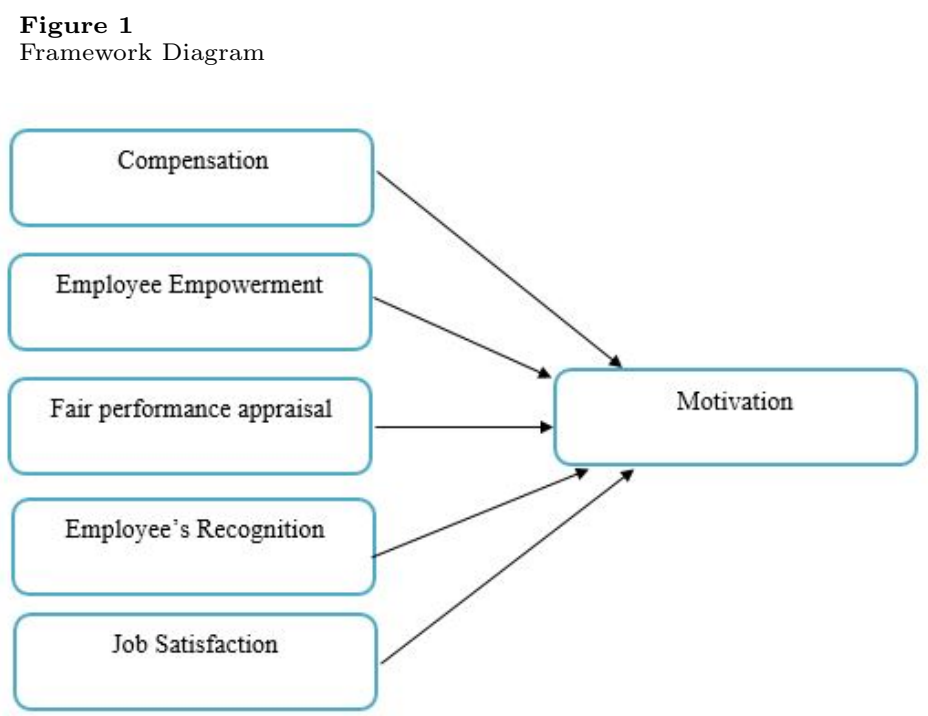

\section{Methodology}

The conceptual framework of this study is represented in figure 1. This framework consists of one dependent variable, employee motivation and 5 independent variables fair job appraisal (FPA), job satisfaction (JS), employee empowerment, (EE), employee recognition (ER) and compensation (Comp). This research investigates these variables in order to study the influence of HR policies on employee motivation in private schools of Karachi, Pakistan.

\section{Measurement instrument}

This research utilizes a questionnaire as its instrument, which is validated by professional experts. A pilot test has been applied in order to validate the instrument by applying the reliability test which is followed by distributing the questionnaire among the teachers of different private schools.

The instrument was constructed on a 5-point Likert scale varying from strongly disagree(1) to strongly agree (5). For this purpose, the items of the variables, employee motivation (Minbaeva, 2008), fair job appraisal (Turk, 2008), job satisfaction (Mak \& Sockel, 2001), employee empowerment (Hong et al., 2012), employee recognition (Chikungwa \& Chamisa, 2013), and compensation (Hong et al., 2012) were adapted and altered in accordance with the context of this study. In order to carry out this research, data together with the demographics, gender, age, and tenure were collected via survey method. Moreover, 
non-probability sampling technique, convenience sampling, was utilized.

In total, 512 responses were collected from the teachers through the questionnaire which contained 32 items meeting the requirement of having 25 items as suggested by Hair et al. (2006). Voluntary responses were gathered from the respondents and it is ensured that the information shared by them is kept confidential. According to the above findings, the mathematical equations of regression method would be:

$$
E M=\alpha+\beta_{1} C+\beta_{2} E E+\beta_{3} F J P+\beta_{4} J S+\epsilon_{t}
$$

Where; $\mathrm{C}=$ compensation, $\mathrm{FJP}=$ fair job appraisal, JS=job satisfaction, $\mathrm{ER}=$ employee recognition, $\mathrm{EE}=$ employee empowerment, $\epsilon_{t}=$ error

\section{Demographics}

Table 1 shows the demographic features of the data. There are 512 respondents (eliminating 20 missing responses) out of which 200 (39\%) are males and $312(61 \%)$ are females. Moreover, $34 \%$ of the respondents are aged between 26-30 while only $5 \%$ are above 50 years. Furthermore, there are $39 \%$ of teachers who have experience of 1 to 5 years whereas only $11 \%$ teachers have experience of more than 15 years.

Table 1

Profile of respondents

\begin{tabular}{lll}
\hline Demographic items & Frequency & Percentile \\
\hline Gender & & \\
Male & 200 & $39 \%$ \\
Female & 312 & $61 \%$ \\
\hline Age & & \\
\hline below25 & & \\
$26-30$ & 56 & $11 \%$ \\
$31-36$ & 174 & $34 \%$ \\
$37-40$ & 108 & $21 \%$ \\
$41-45$ & 102 & $20 \%$ \\
Above 50 & 46 & $9 \%$ \\
Experience & 26 & $5 \%$ \\
\hline Less than 1 & & \\
1-5 & 61 & \\
6 -10 & 200 & $39 \%$ \\
11-15 & 108 & $21 \%$ \\
More than 15 & 87 & $17 \%$ \\
\hline
\end{tabular}

\section{Data Analysis and Results}

For the analysis of data SEM in SmartPLS 3.2.3 (Ringle, Wende, \& Becker, 2014) together with bookstrap resampling technique of 5000 subsamples has been utilized in this research (Hair, Ringle, \& Sarstedt, 2011). 
In order to assess measurement model and the structural model, this method is used since PLS-SEM is suitable for the evaluation of this type of composite model (Hair et al., 2011; Henseler et al., 2014) and it assesses the model accurately (Hair, Sarstedt, Ringle, \& Mena, 2012).

Partial least square was initiated by Wold (1975) and (Joreskog \& Wold, 1982). This method demonstrates the associations among various latent variables. A latent variable is an unobserved variable which links other measured variables. Partial least square is able to operate with latent factors and is also able to deduce the measurement error in the upgrading of unseen constructs (Chin, 1998). This research integrates perception-based items, denoted on a Likert scale, having unidentified distribution and normality which is not exhibited. Moreover, in order to analyze the usefulness of the model, individual item reliability analysis, convergent validity of the measures linked with separate latent variables (Cook, Campbell, \& Day, 1979), and discriminant validity (Campbell \& Fiske, 1959) were utilized.

Table 2

Measurement Model Results

\begin{tabular}{|c|c|c|c|c|}
\hline Constructs & Items & Cronbach's $\alpha$ & Composite reliability & Average Variance extracted \\
\hline \multicolumn{5}{|l|}{ Compensation } \\
\hline & CM1 & & & \\
\hline & CM2 & 0.658 & 0.813 & 0.595 \\
\hline & CM3 & & & \\
\hline \multicolumn{5}{|l|}{ Employee Empowerment } \\
\hline & EE1 & & & \\
\hline & EE2 & 0.633 & 0.782 & 0.476 \\
\hline & EE3 & & & \\
\hline & EE4 & & & \\
\hline \multicolumn{5}{|l|}{ Fair Performance Appraisal } \\
\hline & FPA1 & & & \\
\hline & FPA2 & 0.591 & 0.782 & 0.547 \\
\hline & FPA3 & & & \\
\hline \multicolumn{5}{|l|}{ Employee Recognition } \\
\hline & ER1 & & & \\
\hline & ER2 & 0.604 & 0.765 & 0.453 \\
\hline & ER3 & & & \\
\hline & ER4 & & & \\
\hline \multicolumn{5}{|l|}{ Job Satisfaction } \\
\hline & JS1 & & & \\
\hline & JS3 & 0.542 & 0.738 & 0.418 \\
\hline & JS4 & & & \\
\hline & JS5 & & & \\
\hline \multicolumn{5}{|l|}{ Employee Motivation } \\
\hline & EM1 & & & \\
\hline & EM2 & & & \\
\hline & EM3 & 0.689 & 0.801 & 0.451 \\
\hline & EM4 & & & \\
\hline & EM5 & & & \\
\hline
\end{tabular}

The standardized loadings (or simple correlations) are investigated in order to analyze the individual item reliability. Tabachnick and Fidell (2007); Raza and Hanif (2013); Raza, Jawaid, and Hassan (2015) recommend 0.55 as a cutoff point and the items of this research meet the criteria since their loadings are above 0.55 as shown in table 2 . PLS uses 
two methods for the determination of convergent validity (Fornell \& Larcker, 1981): (1) Cronbach's alpha and composite reliability scores (2) Average variance extracted (AVE).

Table 2 illustrates that all the variables have Cronbach's alpha greater than 0.55 meeting the criteria given by Tabachnick and Fidell (2007); Raza and Hanif (2013); Ali and Raza (2015) and showing that all the variables are reliable except for JS whose reliability is 0.5420. Cronbach's alpha measures the internal consistency of the items (Arif, Aslam, \& Ali, 2016). Nevertheless, all the constructs have their composite reliability, greater than 0.7 as suggested by Nunnally, Bernstein, and Berge (1967).

Table 3

Summary Statistics

\begin{tabular}{lcccccc}
\hline Correlation & CM & EP & FPA & JR & JS & MT \\
\hline CM & 0.771 & & & & & \\
$\mathrm{EE}$ & 0.449 & 0.758 & & & & \\
FPA & 0.621 & 0.471 & 0.739 & & & \\
JR & 0.445 & 0.51 & 0.556 & 0.673 & & \\
JS & 0.473 & 0.493 & 0.392 & 0.471 & 0.644 & \\
MT & 0.527 & 0.483 & 0.532 & 0.557 & 0.511 & 0.671 \\
\hline Notes: CM=Compensation, EE=employee empowerment, FPA= & Fair performance appraisal, ER=employee recognition, JS= Job \\
Fatisfaction, EM= Employee motivation. The diagonal elements \\
(bold) represent the square root of AVE (Average variance extracted)
\end{tabular}

Table 4

Loadings and Cross Loadings

\begin{tabular}{|c|c|c|c|c|c|c|}
\hline & $\mathrm{CM}$ & $\mathrm{EP}$ & FPA & $\mathrm{JR}$ & JS & MT \\
\hline CM1 & 0.730 & 0.419 & 0.461 & 0.319 & 0.371 & 0.329 \\
\hline CM2 & 0.863 & 0.352 & 0.585 & 0.431 & 0.411 & 0.491 \\
\hline CM3 & 0.715 & 0.286 & 0.374 & 0.262 & 0.312 & 0.378 \\
\hline EE1 & 0.261 & 0.702 & 0.332 & 0.332 & 0.278 & 0.337 \\
\hline EE2 & 0.294 & 0.704 & 0.394 & 0.43 & 0.381 & 0.298 \\
\hline EE3 & 0.392 & 0.681 & 0.285 & 0.304 & 0.375 & 0.362 \\
\hline EE4 & 0.283 & 0.674 & 0.299 & 0.353 & 0.329 & 0.331 \\
\hline FPA1 & 0.470 & 0.358 & 0.781 & 0.42 & 0.298 & 0.456 \\
\hline FPA2 & 0.373 & 0.403 & 0.719 & 0.438 & 0.328 & 0.336 \\
\hline FPA3 & 0.532 & 0.295 & 0.724 & 0.386 & 0.252 & 0.378 \\
\hline JR1 & 0.288 & 0.410 & 0.348 & 0.714 & 0.418 & 0.478 \\
\hline JR2 & 0.267 & 0.371 & 0.433 & 0.694 & 0.322 & 0.316 \\
\hline JR3 & 0.260 & 0.256 & 0.283 & 0.621 & 0.212 & 0.311 \\
\hline JR4 & 0.385 & 0.310 & 0.444 & 0.659 & 0.274 & 0.353 \\
\hline JS1 & 0.261 & 0.283 & 0.275 & 0.284 & 0.691 & 0.401 \\
\hline JS2 & 0.308 & 0.366 & 0.236 & 0.316 & 0.628 & 0.291 \\
\hline JS3 & 0.351 & 0.285 & 0.219 & 0.278 & 0.649 & 0.298 \\
\hline JS4 & 0.330 & 0.366 & 0.284 & 0.356 & 0.631 & 0.321 \\
\hline EM1 & 0.303 & 0.355 & 0.349 & 0.394 & 0.318 & 0.661 \\
\hline EM2 & 0.259 & 0.252 & 0.333 & 0.376 & 0.266 & 0.669 \\
\hline EM3 & 0.368 & 0.374 & 0.453 & 0.411 & 0.328 & 0.729 \\
\hline EM4 & 0.398 & 0.256 & 0.331 & 0.349 & 0.356 & 0.651 \\
\hline EM5 & 0.424 & 0.366 & 0.311 & 0.340 & 0.433 & 0.646 \\
\hline
\end{tabular}


Furthermore, the average variance extracted should be greater than 0.5 for the determination of convergent validity (Fornell \& Larcker, 1981) and from Table 2 it can be deduced that all the variables have their AVE greater than 0.5.

For the assessment of discriminant validity, cross-loadings, square root of average variance extracted (AVE) and heterotrait-monotrait ratio of correlations are analyzed. Table 3 shows the correlation matrix in which the square root of AVE is greater than the correlation of latent variables and this outcome adheres to the criterion given by Fornell and Larcker (1981). Analysis of cross loadings can be done from table 4 which shows that cross loadings of each item is greater on its corresponding variable and also the differences of cross loadings are greater than the benchmark (Gefen \& Straub, 2000). Table 5 represents heterotrait-monotrait ratio of correlations (HTMT) in which all the values are below 0.85 which is the requirement (Henseler, Ringle, \& Sarstedt, 2015; Raza, Qazi, \& Umer, 2016).

Table 5

\begin{tabular}{llllll}
\multicolumn{5}{c}{ Heterotrait-Monotrait Ratio (HTMT) Results } \\
\hline \multicolumn{7}{c}{ CM } & EP & FPA & JR & JS & MT \\
\hline CM & & & & & \\
EE & 0.699 & & & & \\
FPA & 0.839 & 0.775 \\
JR & 0.688 & 0.81 & 0.832 & & \\
JS & 0.793 & 0.842 & 0.682 & 0.788 & \\
EM & 0.754 & 0.714 & 0.809 & 0.829 & 0.803 \\
\hline Notes: CM=Compensation, EE=employee \\
empowerment FPA=fair performance appraisal, \\
ER=employee recognition, JS=job satisfaction, \\
EM=employee motivation.
\end{tabular}

The explanatory strength of the model can be evaluated by measuring the quantity of variance in the dependent construct which can be predicted by the model. Analysts (Breiman \& Friedman, 1985) regard $R^{2}$ to be vital for the calculation of a structural model. $R^{2}$ for the dependent variable, employee motivation, is 0.48 as shown in figure. 2. This implies that $48 \%$ of the changes in the employee motivation are due to five independent variables in the variables.

\section{Path Analysis}

Table 6

Standardized regression weights for the research model

\begin{tabular}{lllll}
\hline Hypothesis & Regression Path & Effect type & SRW & Remarks \\
\hline H1 & CM ->MT & Direct effect & 0.173 & Supported \\
H2 & EP ->MT & Direct effect & 0.115 & Supported \\
H3 & FPA ->MT & Direct effect & 0.168 & Supported \\
H4 & JR - > MT & Direct effect & 0.237 & Supported \\
H5 & JS - $>$ MT & Direct effect & 0.199 & Supported \\
\hline \multicolumn{4}{l}{ Notes: SRW $=$ Standardized regression weight }
\end{tabular}

Figure 2 and table 6 also represent the path analysis showing the correlation of each path with the hypothesis. The coefficients through their sign, size and significance examine 
the hypotheses between dependent and independent variables (Wixom \& Watson, 2001). Moreover, the larger the value of coefficients, the stronger the impact of the latent variable is on the dependent variable. Also, the significance of the hypotheses is determined by taking level of significance into account which is supposed to be less than 0.1. Hence, all the paths are significant as can be seen in figure 2 .

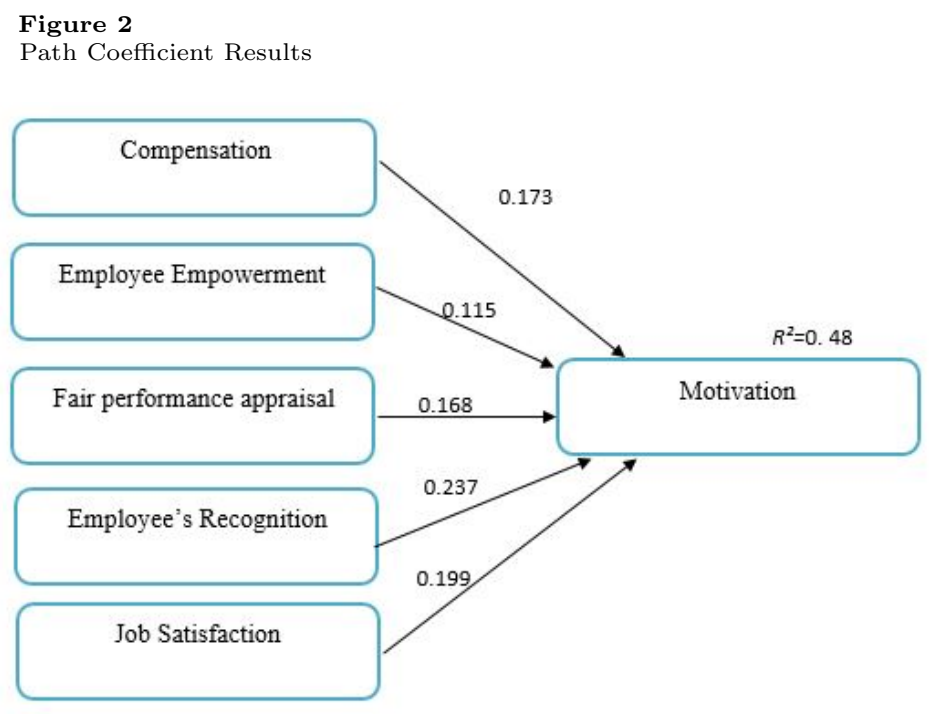

The findings suggest that coefficients of all the paths are positive and significant, thus verifying $\mathrm{H} 1, \mathrm{H} 2, \mathrm{H} 3, \mathrm{H} 4$ and $\mathrm{H} 5$.

\section{Discussion and conclusion}

The aforementioned outcomes represent that the paths between all the independent variables and dependent variables are positive and significant, implying that all the hypotheses are verified. The path linking compensation and employee motivation is positive and significant $(\beta=0.1800, p<0.1)$ thus supporting the hypothesis H1. This finding is similar with the outcomes of other studies (Hong et al., 2012; Turk, 2008; Van Herpen et al., 2005; Chiu, Wai-Mei Luk, \& Li-Ping Tang, 2002). Hence, it is concluded that compensation positively affects employee motivation.

Likewise, the path linking employee empowerment and employee motivation is positive and significant $(\beta=0.108, p<0.1)$, supporting $\mathrm{H} 2$. This outcome is also similar with other study (Tutar et al., 2011) hence showing that employee empowerment has a positive impact on employee motivation. Moreover, the path H3 is also supported since the path between a fair job appraisal and employee motivation is positive and significant $(\beta=$ $0.159, p<0.1$ ), showing that fair job appraisal positively affects employee motivation. This result is congruent with the results of the previous research (Jabeen, 2011; Turk, 2008). 
Again, the path connecting employee recognition and employee motivation is positive and significant $(\beta=0.2410, p<0.1)$, supporting the hypothesis $\mathrm{H} 4$ and implying that employee recognition has a positive impact on motivation. This result is also consistent with the results of other studies (Chikungwa \& Chamisa, 2013). Lastly, H5 is also supported as the path linking job satisfaction and employee motivation is positive and significant (Stringer et al., 2011).

This study analyzed the impact of HR policies on employee motivation and precisely considered factors such as compensation, employee empowerment, fair job appraisal, employee recognition and job satisfaction. Data were collected through a questionnaire from the employees of different schools in Karachi and tested through PLS-SEM technique. The results conclude that HR policies do have a positive impact on the motivation of employees.

\section{Practical implications}

This research gives a view of the importance and impact of HR policies on the motivation of employees belonging to the private schools of Karachi Pakistan. Every policy of human resource has a significant role in motivating employees. This has been confirmed from the results discussed above.

The outcomes discovered from this research are beneficial to the management of educational institutions as it can provide them with the ways to incorporate strategies in order to motivate their employees. This study also investigates how the workers visualize the significance of factors like compensation, employee empowerment, employee recognition, job satisfaction and fair job appraisal while contributing their efforts for the well-being of the organization. Today, these are the vital HR features used by the management to assist their strategic management.

Moreover, the outcome suggests that workers are mostly affected by these variables since close association is observed between the independent and dependent variables. Thus, management should comprehend the requirement of workers in gaining knowledge, building their expertise, delegation of authority, viable compensation and acknowledgement of the current evaluation process. The research proposes that when the management satisfies their workers fully, the likelihood of employees getting motivated highly increases.

Furthermore, this research provides a chance for not only schools but business companies to deploy these factors in order to entice new talents at one hand and to build its own goodwill in the market on the other hand. Also motivating the employees will eventually help the organization since by doing so, the performance and efficiency will be enhanced.

\section{Limitations}

The results of this study cannot be generalized as the data are collected from a limited number of schools and only one city is focused i.e, Karachi. Moreover, the restricted number of factors of $\mathrm{HR}$ policies is considered while studying its impact on employee motivation. The study could be stretched by the other factors of HR policies which could affect employee motivation, such as training and development, career development, talent 
management and employee engagement. Also, the research could be carried out on the employees of higher education institutions. 


\section{References}

Alam, M., Shaheed, A., Sahabuddin, M., \& Akter, S. (2013). Relationship between employee recognition and employee contribution in service industry. International Journal of Business and Marketing Management, 1(1), 1-8.

Ali, M., \& Raza, S. A. (2015). Service quality perception and customer satisfaction in islamic banks of pakistan: the modified servqual model. Total Quality Management E Business Excellence, 1-19. doi: 10.1080/14783363.2015.1100517

Allan, P. (1994). Designing and implementing an effective performance appraisa. Review of Business, 16(2), 3-8.

Arif, I., Aslam, W., \& Ali. (2016). Students' dependence on smartphones and its effect on purchasing behavior. South Asian Journal of Global Business Research, 5(2), 285-302.

Baron, R. A., Greenberg, J., DeNisi, A. S., \& Goddard, R. (1990). Behavior in organizations: Understanding and managing the human side of work. Allyn and Bacon Boston.

Batt, R. (2002). Managing customer services: Human resource practices, quit rates, and sales growth. Academy of Management Journal, 45(3), 587-597.

Boyd, N. M. (2004). Expanding the view of performance appraisal by introducing social justice concerns. Administrative Theory \& Praxis, 26(3), 249-278.

Breiman, L., \& Friedman, J. H. (1985). Estimating optimal transformations for multiple regression and correlation. Journal of the American Statistical Association, 80(391), 580-598.

Campbell, D. T., \& Fiske, D. W. (1959). Convergent and discriminant validation by the multitrait-multimethod matrix. Psychological Bulletin, 56(2), 81-105.

Chikungwa, T., \& Chamisa, S. F. (2013). An evaluation of recognition on performance as a motivator: A case of eastern cape higher education institution. Mediterranean Journal of Social Sciences, 4(14), 219-225.

Chin, W. W. (1998). The partial least squares approach to structural equation modeling. Modern Methods for Business Research, 295(2), 295-336.

Chiu, R. K., Wai-Mei Luk, V., \& Li-Ping Tang, T. (2002). Retaining and motivating employees: Compensation preferences in hong kong and china. Personnel Review, $31(4), 402-431$.

Conger, J. A., \& Kanungo, R. N. (1988). The empowerment process: Integrating theory and practice. Academy of Management Review, 13(3), 471-482.

Cook, T. D., Campbell, D. T., \& Day, A. (1979). Quasi-experimentation: Design \& analysis issues for field settings. Houghton Mifflin Boston.

Cranny, C., Smith, P. C., \& Stone, E. (1992). Job satisfaction: How people feel about their jobs. New York:Lexington Press.

Deci, E. L., \& Vroom, V. H. (1992). Management and motivation: selected readings. Penguin Books.

Delery, J. E., \& Shaw, J. D. (2001). The strategic management of people in work organizations: Review, synthesis, and extension. , 20, 165-197. 
Fornell, C., \& Larcker, D. F. (1981). Evaluating structural equation models with unobservable variables and measurement error. Journal of Marketing Research, 18(1), $39-50$.

Gagne, M., Senecal, C. B., \& Koestner, R. (1997). Proximal job characteristics, feelings of empowerment, and intrinsic motivation: a multidimensional model1. Journal of Applied Social Psychology, 27(14), 1222-1240.

Gefen, D., \& Straub, D. W. (2000). The relative importance of perceived ease of use in is adoption: A study of e-commerce adoption. Journal of the Association for Information Systems, 1(1), 8.

Georgellis, Y., Lange, T., Ileana Petrescu, A., \& Simmons, R. (2008). Human resource management practices and workers' job satisfaction. International Journal of Manpower, 29(7), 651-667.

Hair, J. F., Black, W. C., Babin, B. J., Anderson, R. E., Tatham, R. L., et al. (2006). Multivariate data analysis (Vol. 6). Pearson Prentice Hall Upper Saddle River, NJ.

Hair, J. F., Ringle, C. M., \& Sarstedt, M. (2011). Pls-sem: Indeed a silver bullet. Journal of Marketing Theory and Practice, 19(2), 139-152.

Hair, J. F., Sarstedt, M., Ringle, C. M., \& Mena, J. A. (2012). An assessment of the use of partial least squares structural equation modeling in marketing research. Journal of the Academy of Marketing Science, 40(3), 414-433.

Hellriegel, D., \& Slocum, J. W. (1974). Organizational climate: Measures, research and contingencies. Academy of Management Journal, 17(2), 255-280.

Henseler, J., Dijkstra, T. K., Sarstedt, M., Ringle, C. M., Diamantopoulos, A., Straub, D. W., ... Calantone, R. J. (2014). Common beliefs and reality about pls comments on ronkko and evermann (2013). Organizational Research Methods, 1094428114526928.

Henseler, J., Ringle, C. M., \& Sarstedt, M. (2015). A new criterion for assessing discriminant validity in variance-based structural equation modeling. Journal of the Academy of Marketing Science, 43(1), 115-135.

Herzberg, F. M. (1959). B. \& snyderman, b.(1959). the motivation to work. 2, li.

Hong, E. N. C., Hao, L. Z., Kumar, R., Ramendran, C., \& Kadiresan, V. (2012). An effectiveness of human resource management practices on employee retention in institute of higher learning: A regression analysis. International Journal of Business Research and Management, 3(2), 60-79.

Howard, J. L., \& Frink, D. D. (1996). The effects of organizational restructure on employee satisfaction. Group \&S Organization Management, 21(3), 278-303.

Hoy, W. K., \& Miskel, C. G. (2005). Educational administration: Theory, research, and practice. McGraw-Hill.

Hui, L., \& Qin-xuan, G. (2009). Performance appraisal: what's the matter with you? Procedia Earth and Planetary Science, 1(1), 1751-1756.

Jabeen, M. (2011). Impact of performance appraisal on employees motivation. European Journal of Business and Management, 3(4), 197-204.

Jaffery, H., Farooq, H., et al. (2015). The impact of structural empowerment on organizational citizenship behavior-organization and job performance: A mediating role of burnout. Journal of Management Sciences, 2(2), 273-288. 
Jarrar, Y. F., \& Zairi, M. (2002). Employee empowerment-a uk survey of trends and best practices. Managerial Auditing Journal, 17(5), 266-271.

Joreskog, K. G., \& Wold, H. O. (1982). Systems under indirect observation: Causality, structure, prediction. Amsterdam: North Holland.

Kalyani, M., \& Sahoo, M. P. (2011). Human resource strategy: a tool of managing change for organizational excellence. International Journal of Business and Management, $6(8), 280-293$.

Kaye, B., \& Jordan-Evans, S. (2001). Retaining key employees. Public Management Review, 83(1), 47-73.

Klagge, J. (1998). The empowerment squeeze-views from the middle management position. Journal of Management Development, 17(8), 548-558.

Kleiner, M. M. (1990). The role of industrial relations in firm performance. Employee and Labor Relations, 4, 423-443.

Kreitner, R. (1995). Management boston. Houghtoon Mifflin Group Company.

Laursen, K., Foss, N., et al. (2000). New hrm practices, complementarities, and the impact on innovation performance (Tech. Rep.). Department of Industrial Economics and Strategy, Copenhagen Business School.

Lawler, E. E. (1981). Pay and organization development (Vol. 3990). Prentice Hall.

Lawler, E. E. (2003). Reward practices and performance management system effectiveness. Organizational Dynamics, 32(4), 396-404.

Lawler, E. E., Mohrman, A. M., \& Resnick, S. M. (1984). Performance appraisal revisited. Organizational Dynamics, 13(1), 20-35.

Lawler III, E. E. (1973). Motivation in work organizations.

Lawson, P. (2000). 17 performance-related pay. In Strategic reward system (p. 302-318). London: Financial Times.

Locke, E. A. (1976). The nature and causes of job satisfaction. Handbook of Industrial and Organizational Psychology, 1, 1297-1343.

Locke, E. A., Shaw, K. N., Saari, L. M., \& Latham, G. P. (1981). Goal setting and task performance: 1969-1980. Psychological bulletin, 90(1), 125-139.

Mak, B. L., \& Sockel, H. (2001). A confirmatory factor analysis of is employee motivation and retention. Information \& Management, 38(5), 265-276.

Manjunath, V., \& Rajesh, C. (2012). Competency based compensation system-as a strategic human resource technique. International Journal of Manpower, 38(7), 780-810.

Martin, D. E. (2011). Internal compensation structuring and social bias: Experimental examinations of point. Personnel Review, 40 (6), 785-804.

Minbaeva, D. B. (2008). Hrm practices affecting extrinsic and intrinsic motivation of knowledge receivers and their effect on intra-mnc knowledge transfer. International Business Review, 17(6), 703-713.

Molineux, J. (2013). Enabling organizational cultural change using systemic strategic human resource management-a longitudinal case study. The International Journal of Human Resource Management, 24 (8), 1588-1612.

Mossholder, K. W., Richardson, H. A., \& Settoon, R. P. (2011). Human resource systems and helping in organizations: A relational perspective. Academy of Management Review, 36(1), 33-52. 
Nohria, N., Groysberg, B., \& Lee, L. (2008). Employee motivation: A powerful new model. Harvard Business Review, 86(7/8), 78-87.

Nunnally, J. C., Bernstein, I. H., \& Berge, J. M. t. (1967). Psychometric theory (Vol. 226). New York: McGraw Hill.

O'Reilly, C. A., Chatman, J., \& Caldwell, D. F. (1991). People and organizational culture: A profile comparison approach to assessing person-organization fit. Academy of Management Journal, 34(3), 487-516.

Patterson, M. G., West, M. A., Lawthom, R., \& Nickell, S. (1997). Impact of people management practices on business performance. Institute of Personnel and Development London.

Pool, S. W. (1997). The relationship of job satisfaction with substitutes of leadership, leadership behavior, and work motivation. The Journal of Psychology, 131(3), 271283.

Porter, L. W., \& Lawler, E. E. (1968). Managerial attitudes and performance.

Quinn, R. E., \& Spreitzer, G. M. (1997). The road to empowerment: Seven questions every leader should consider. Organizational Dynamics, 26(2), 37-49.

Raza, S. A., \& Hanif, N. (2013). Factors affecting internet banking adoption among internal and external customers: a case of pakistan. International Journal of Electronic Finance, 7(1), 82-96.

Raza, S. A., Jawaid, S. T., \& Hassan, A. (2015). Internet banking and customer satisfaction in Pakistan. Qualitative Research in Financial Markets, 7(1), 24-36.

Raza, S. A., Qazi, W., \& Umer, A. (2016). Facebook Is a Source of Social Capital Building Among University Students Evidence From a Developing Country. Journal of Educational Computing Research. doi: 10.1177/0735633116667357

Ringle, C. M., Wende, S., \& Becker, J.-M. (2014). Smartpls 3. Hamburg: SmartPLS.

Sial, M. A., Jilani, S. M. A., Imran, R., \& Zaheer, A. (2011). Effect of human resource practices on organizational commitment in pakistani universities. World Applied Sciences Journal, 15(6), 793-798.

Smith, G. (1994). Motivation, hi: W. tracey. Human Resource Management and Development Handbook.

Spreitzer, G. M. (1995). Psychological empowerment in the workplace: Dimensions, measurement, and validation. Academy of Management Journal, 38(5), 1442-1465.

Stavrou, E. T. (2005). Flexible work bundles and organizational competitiveness: a crossnational study of the european work context. Journal of Organizational Behavior, $26(8), 923-947$.

Stringer, C., Didham, J., \& Theivananthampillai, P. (2011). Motivation, pay satisfaction, and job satisfaction of front-line employees. Qualitative Research in Accounting 8 Management, 8(2), 161-179.

Tabachnick, B., \& Fidell, L. (2007). Multivariate analysis of variance and covariance (Vol. 3). Allyn \& Bacon Boston, MA.

Tomlinson, H. (2000). Proposals for performance related pay for teachers in english schools. School Leadership \& Management, 20(3), 281-298.

Tsui, A. S., Pearce, J. L., Porter, L. W., \& Tripoli, A. M. (1997). Alternative approaches to the employee-organization relationship: does investment in employees pay off? 
Academy of Management Journal, 40(5), 1089-1121.

Turk, K. (2008). Performance appraisal and the compensation of academic staff in the university of tartu. Baltic Journal of Management, 3(1), 40-54.

Tutar, H., Altinoz, M., \& Cakiroglu, D. (2011). The effects of employee empowerment on achievement motivation and the contextual performance of employees. African Journal of Business Management, 5(15), 6318-6324.

Van Herpen, M., Van Praag, M., \& Cools, K. (2005). The effects of performance measurement and compensation on motivation: An empirical study. De Economist, 153(3), 303-329.

Vogt, J. F. (1990). Empowerment in organizations: How to spark exceptional performance. Pfeiffer \& Company.

Vroom, V. H. (1964). Work and motivation. New York:Wiley.

Weiss, W. (2001). Appraising employee performance. Supervision, 62 (10), 10-12.

Wixom, B. H., \& Watson, H. J. (2001). An empirical investigation of the factors affecting data warehousing success. MIS quarterly, 25(1), 17-41.

Wold, H. (1975). Modelling in complex situations with soft information. In Third world congress of econometric society (pp. 21-26). 